NASA/TM-2003-212085

\title{
Cryogenic Evaluation of an Advanced DC/DC Converter Module for Deep Space Applications
}

Malik E. Elbuluk

University of Akron, Akron, Ohio

Ahmad Hammoud

QSS Group, Inc., Cleveland, Ohio

Scott S. Gerber

ZIN Technologies, Inc., Brook Park, Ohio

Richard Patterson

Glenn Research Center, Cleveland, Ohio 
Since its founding, NASA has been dedicated to the advancement of aeronautics and space science. The NASA Scientific and Technical Information (STI) Program Office plays a key part in helping NASA maintain this important role.

The NASA STI Program Office is operated by Langley Research Center, the Lead Center for NASA's scientific and technical information. The NASA STI Program Office provides access to the NASA STI Database, the largest collection of aeronautical and space science STI in the world. The Program Office is also NASA's institutional mechanism for disseminating the results of its research and development activities. These results are published by NASA in the NASA STI Report Series, which includes the following report types:

- TECHNICAL PUBLICATION. Reports of completed research or a major significant phase of research that present the results of NASA programs and include extensive data or theoretical analysis. Includes compilations of significant scientific and technical data and information deemed to be of continuing reference value. NASA's counterpart of peerreviewed formal professional papers but has less stringent limitations on manuscript length and extent of graphic presentations.

- TECHNICAL MEMORANDUM. Scientific and technical findings that are preliminary or of specialized interest, e.g., quick release reports, working papers, and bibliographies that contain minimal annotation. Does not contain extensive analysis.

- CONTRACTOR REPORT. Scientific and technical findings by NASA-sponsored contractors and grantees.
- CONFERENCE PUBLICATION. Collected papers from scientific and technical conferences, symposia, seminars, or other meetings sponsored or cosponsored by NASA.

- SPECIAL PUBLICATION. Scientific, technical, or historical information from NASA programs, projects, and missions, often concerned with subjects having substantial public interest.

- TECHNICAL TRANSLATION. Englishlanguage translations of foreign scientific and technical material pertinent to NASA's mission.

Specialized services that complement the STI Program Office's diverse offerings include creating custom thesauri, building customized databases, organizing and publishing research results... even providing videos.

For more information about the NASA STI Program Office, see the following:

- Access the NASA STI Program Home Page at http://www.sti.nasa.gov

- E-mail your question via the Internet to help@sti.nasa.gov

- Fax your question to the NASA Access Help Desk at 301-621-0134

- Telephone the NASA Access Help Desk at $301-621-0390$

- Write to:

NASA Access Help Desk NASA Center for AeroSpace Information 7121 Standard Drive Hanover, MD 21076 
NASA/TM-2003-212085

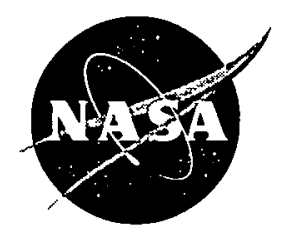

\section{Cryogenic Evaluation of an Advanced DC/DC Converter Module for Deep Space Applications}

Malik E. Elbuluk

University of Akron, Akron, Ohio

Ahmad Hammoud

QSS Group, Inc., Cleveland, Ohio

Scott S. Gerber

ZIN Technologies, Inc., Brook Park, Ohio

Richard Patterson

Glenn Research Center, Cleveland, Ohio

Prepared for the

37th Industry Application Society Annual Meeting cosponsored by the Institute of Electrical and Electronics Engineers and the Instrument Society of America

Pittsburgh, Pennsylvania, October 13-17, 2002

National Aeronautics and

Space Administration

Glenn Research Center 


\section{Acknowledgments}

This work is supported by the NASA Glenn Research Center, GESS Contract number NAS3-00145.

This report is a formal draft or working paper, intended to solicit comments and ideas from a technical peer group.

This report contains preliminary
findings, subject to revision as
analysis proceeds.

Available from

NASA Center for Aerospace Information

7121 Standard Drive

Hanover, MD 21076
National Technical Information Service 5285 Port Royal Road Springfield, VA 22100 


\section{Cryogenic Evaluation of an Advanced DC/DC Converter Module for Deep Space Applications}

\author{
Malik E. Elbuluk \\ University of Akron \\ Akron, Ohio 44325 \\ Phone: 330-972-6531 \\ E-mail: melbuluk@uakron.edu \\ Ahmad Hammoud \\ QSS Group, Inc. \\ Cleveland, Ohio 44135 \\ Phone: 216-433-8511 \\ E-mail: Ahmad.hammoud@grc.nasa.gov
}

\author{
Scott S. Gerber \\ ZIN Technologies \\ Brook Park, Ohio 44142 \\ Phone: 216-433-5226 \\ E-mail: scott.s.gerberagrc.nasa.gov \\ Richard Patterson \\ NASA Glenn Research Center \\ Cleveland, Ohio 44135 \\ Phone: $216-433-8166$ \\ E-mail: richard.patterson agrc.nasa.gov
}

\begin{abstract}
DC/DC converters are widely used in power management, conditioning, and control of space power systems. Deep space applications require electronics that withstand cryogenic temperature and meet a stringent radiation tolerance. In this work, the performance of an advanced, radiation-hardened (rad-hard) commercial DC/DC converter module was investigated at cryogenic temperatures. The converter was investigated in terms of its steady state and dynamic operations. The output voltage regulation, efficiency, terminal current ripple characteristics, and output voltage response to load changes were determined in the temperature range of 20 to $-140{ }^{\circ} \mathrm{C}$. These parameters were obtained at various load levels and at different input voltages. The experimental procedures along with the results obtained on the investigated converter are presented and discussed.
\end{abstract}

\section{INTRODUCTION}

In many future space missions, such as outer planetary exploration and deep space probes, electrical and electronic power components and systems must operate reliably and efficiently in very low temperature environments. For example, an interplanetary probe launched to explore the rings of Saturn would experience an average temperature of about $-183^{\circ} \mathrm{C}$. Presently, spacecraft operating in the cold environment of deep space carry on-board a large number of radioisotope heating units to maintain an operating temperature for the electronics of approximately $20^{\circ} \mathrm{C}$. This is not an ideal solution because the radioisotope units are always producing heat, even when the spacecraft is already too hot, thus requiring an active thermal control system for the spacecraft. Electronics capable of operation at cryogenic temperatures will not only tolerate the hostile environment of deep space but also reduce system size and weight by eliminating the heating radioisotope units and associated structures thereby; reducing system development and launch costs, improving reliability and lifetime, and increasing energy densities.

The Low Temperature Electronics Program at the NASA Glenn Research Center (GRC) focuses on research and development of electrical components and systems suitable for applications in deep space missions. Research is being conducted on components and systems for use down to cryogenic temperature $\left(-196^{\circ} \mathrm{C}\right)$. These include commercially available semiconductor switching devices, resistors, magnetic components, capacitors, integrated circuits and DC/DC converter modules. Also, a number of DC/DC converters have been built and characterized inhouse at low temperatures. The converters were designed or modified to operate from room temperature to $-196^{\circ} \mathrm{C}$ using commercially available components. These systems had output power range from $5 \mathrm{~W}$ to $1 \mathrm{~kW}$ with switching frequencies of 50 to $200 \mathrm{kHz}$. [1-14].

In this work, an advanced commercial-off-theshelf modular DC/DC converter has been investigated for low temperature operation. The converter has a high power density $\left(30 \mathrm{~W} / \mathrm{in}^{3}\right)$ and has been spacequalified in terms of radiation tolerance. It is a singleended forward converter with a constant switching frequency of $550 \mathrm{kHz}$. It has a wide input voltage range of 16 to $40 \mathrm{~V}$, an output voltage of $3.3 \mathrm{~V}$ and a power rating of $10 \mathrm{~W}$. Its operating temperature range is specified between $-55^{\circ} \mathrm{C}$ to $125^{\circ} \mathrm{C}$. The module was investigated in terms of its steady state output voltage regulation, efficiency, terminal current ripple characteristics, and dynamic response of the output voltage to a step change in load. These properties, which were determined in the temperature range of 20 to $-140{ }^{\circ} \mathrm{C}$, were obtained at various load levels and at different input voltages. The experimental procedures along with the experimental data obtained on the investigated converter are presented and discussed. 


\section{EXPERIMENTAL SETUP AND PROCEDURES}

The tests on the converter were performed using an environmental chamber utilizing liquid nitrogen as the coolant. A temperature rate of change of $10^{\circ} \mathrm{C} / \mathrm{min}$ was used throughout this work. The module was investigated in the temperature range of 20 to $-140^{\circ} \mathrm{C}$ at a decrement of $20^{\circ} \mathrm{C}$. At a given temperature, these properties were obtained at various input voltages and at different load levels from no-load to full-load conditions. At every test temperature, the test article was allowed to soak at that temperature for a period of 30 minutes before any measurements were made. After the last measurement was taken at the lowest temperature, the converter was allowed to stabilize to room temperature, and then the measurements were repeated at room temperature to determine the effect of thermal cycling on the converter's performance.

\section{RESULTS AND DISCUSSIONS}

The converter was evaluated under steady state and dynamic conditions. In the steady state, the converter output voltage regulation, efficiency, and input and output current distortions were investigated. At a given temperature, these properties were obtained at various input voltages and at different load levels, from no-load to full-load conditions.

The dynamic characteristics of the converter were obtained by monitoring the transient response of the output voltage due to a step change in the load. Two responses were recorded, one from no load to full load and the other from full load to no load.

\section{A. Steady State Performance}

The output voltage and efficiency of the converter at various input voltage and load levels as a function of temperature are shown in Figures 1 through 4 . These parameters are obtained utilizing input voltages of $16,24,32$, and $42 \mathrm{~V}$ for loads of $0.5,1.0,1.5,2.0$, and $2.5 \mathrm{~A}$. The converter exhibited good voltage regulation with temperature down to $-100{ }^{\circ} \mathrm{C}$. This trend is maintained regardless of the load level to which the converter is subjected. Below $-100{ }^{\circ} \mathrm{C}$, however, the converter started to display inconsistent behavior in its voltage regulation, particularly with an applied input voltage of $16 \mathrm{~V}$. At this voltage level, the efficiency of the converter tends to slightly decrease with a decrease in test temperature down to $-100^{\circ} \mathrm{C}$, as shown in Figure 1. This decrease becomes more significant at temperatures below $-100^{\circ} \mathrm{C}$. At any given test temperature, the efficiency increased as the load was increased. At temperatures below $-100^{\circ} \mathrm{C}$, the efficiency is at minimum as the converter exhibits some loss in output regulation.

At input voltage higher than $16 \mathrm{~V}$, the converter displayed better stability in its voltage regulation throughout the entire test temperature range from 20 to $-140^{\circ} \mathrm{C}$, as shown in Figures 2 to 4 . Such is the case at any load level investigated between 0.5 and $2.5 \mathrm{~A}$. The efficiency of the converter, displayed similar behavior to that observed under $16 \mathrm{~V}$ input between 20 and $-100^{\circ} \mathrm{C}$. Once again, the efficiency, at a given test temperature, has the highest value when the maximum loading level was applied to the converter.

Waveforms of the converter output voltage ripple, the output current ripple, and the input current ripple at room temperature $\left(25^{\circ} \mathrm{C}\right)$ and at a low temperature $\left(-100^{\circ} \mathrm{C}\right)$ are shown in Figures 5 and 6 for light load and heavy load, respectively. Theses waveforms were obtained using an input voltage of $16 \mathrm{~V}$. No effect of temperature can be observed as no significant variations occur in these waveforms.

Figures 7 and 8 show the same waveforms both at room temperature $\left(25^{\circ} \mathrm{C}\right)$ and at the low temperature $\left(-100^{\circ} \mathrm{C}\right)$ for high input voltage of $40 \mathrm{~V}$. Once again, these properties do not undergo much change in their waveforms due to the temperature variation from 20 to $-100^{\circ} \mathrm{C}$, regardless of the applied load. The level of the applied input, however, seems to influence these properties as evident from the increase in the frequency as well as the amplitude of the ripples as higher voltages are applied.

\section{B. Dynamic Performance}

The dynamic response for the converter, represented by output voltage response to a step change in the load current, is shown in Figures 9 and 10. The step change from full load to no load exhibited different dynamic response compared to that of a step change from no load to full load. The different responses are a clear indication of the nonlinear behavior of the module and may also reflect the effect of low temperature on the components and devices in the converter.

\section{Conclusions}

An advanced radiation-hardened DC/DC converter was characterized in terms of its performance as a function of temperature in the range of 20 to $-140^{\circ} \mathrm{C}$. The converter was evaluated with respect to its steady state output voltage regulation, efficiency, output voltage ripple; input current ripple and output current ripple at various input voltage levels and loads. In general, this converter displayed good performance in regulation, efficiency and dynamic characteristics with 
temperature down to $-100^{\circ} \mathrm{C}$. Some instability is observed as the temperature is decreased further. More testing under long-term thermal exposure is needed to fully characterize this converter for potential application in low temperature environments.

\section{REFERENCES}

1. Ray, B., Gerber, S.S., Patterson, R. and Myers, I., "Power Control Electronics for Cryogenic Instrumentation," Advances in Inst. and Control, Vol. 50, Part 1, Int. Soc. for Measurement and Control, 1995, pp. 131-139.

2. Patterson, R.L., Dickman, J.E., Hammoud, A. and Gerber S.S., "Low Temperature Power Electronics Program," NASA EEE Links, Electronic Packaging and Space Parts News, Vol. 4, No. 1, January 1998.

3. Patterson, R.L., Hammoud, A. and Gerber, S.S., "Evaluation of Capacitors at Cryogenic Temperatures for Space Applications," IEEE International Conference on Electrical Insulation, Washington DC, June 7-10, 1998.

4. Ray, B., Gerber, S., Patterson, R. and Myers, I., "77K Operation of a Multi-Resonant Power Converter," IEEE PESC, Record, Vol. 1, 1995, pp. 55-60.

5. Ray, B., Gerber, S.S., Patterson, R.L. and Myers, I.T., "Liquid Nitrogen Temperature Operation of a Switching Power Converter," Symp. on Low Temp. Electronics \& High Temperature Superconductivity, Electrochemical Society, Vol. 9, 1995, pp. 345-352.

6. Ray, B., Gerber, S.S., Patterson, R.L. and Dickman, J., "Low Temperature Performance of a Boost Converter with MPP and HTS Inductor," IEEE APEC 96 Conference, Vol. 2, 1996, pp. 883-888.
7. Gerber, S.S., Patterson, R.L., Ray, B. and Stell, C., "Performance of a Spacecraft DC-DC Converter Breadboard Modified for Low Temperature Operation," IECEC 96, Vol. 1, 1996, pp. 592-598.

8. Ray, B., Gerber, S.S. and Patterson, R.L., "Low Temperature Performance of a Full-Bridge DC-DC Converter," IECEC '96, Vol. 1, 1996, pp. 553-559.

9. Gerber, S.S. Miller, T., Patterson, R.L. and Hammoud, A., "Performance of a Closed-Loop Controlled High Voltage DC/DC Converter at Cryogenic Temperature," IECEC '98, Vol. 1, 1998.

10. M. Elbuluk, S. Gerber, A. Hammoud and R. Patterson, "Evaluation of Low Power DC/DC Converter Modules at Low Temperatures," Proceedings of IEEE PESC'00, Galway, Ireland.

11. Elbuluk, S. Gerber, A. Hammoud and R. Patterson, "Efficiency and Regulation of Low Power DC/DC Converter Modules at Cryogenic Temperatures," Proceedings of IEEE IECEC'00, Las Vegas.

12. M. Elbuluk, S. Gerber, A. Hammoud and R. Patterson, "Characterization of Low Power DC/DC Converter Modules at Low Temperatures," Proceedings of IEEE IAS'00, Rome, Italy.

13. S. Gerber, A. Hammoud, M. Elbuluk, R. Patterson, R. Ghaffarian, R. Ramesham and S. Agarwal, "Low Temperature Testing of a Radiation Hardened CMOS 8Bit Flash Analog-to-Digital (A/D) Converter," $36^{\text {th }}$ Intersociety Energy Conversion Engineering Conference (IECEC), Savannah, Georgia, July 29-Aug 2, 2001.

14. M. Elbuluk, S. Gerber, A. Hammoud, and R. Patterson, "Performance of High-Speed PWM Control Chips at Cryogenic Temperatures," Proceedings of IEEE LAS'01, Chicago, October 2001.
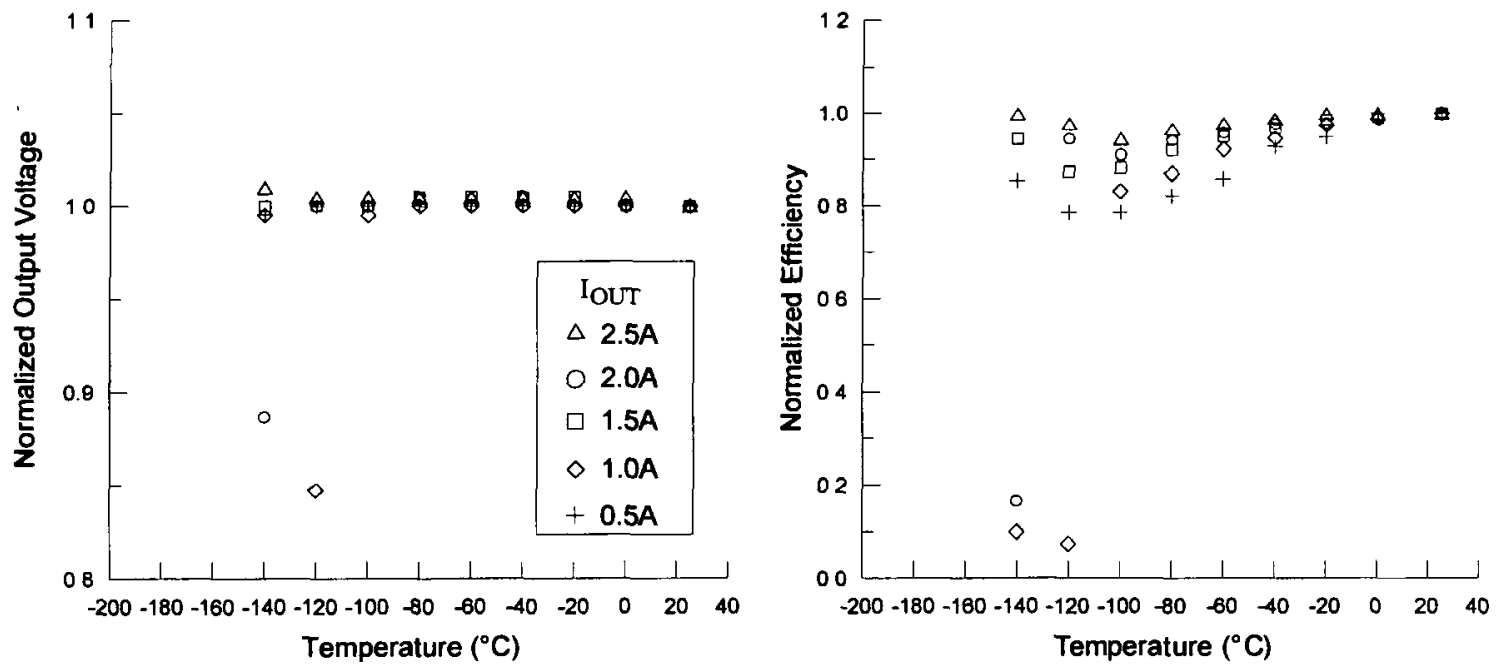

Figure 1. Output voltage and efficiency versus temperature at various loads and input voltage of $16 \mathrm{~V}$. 

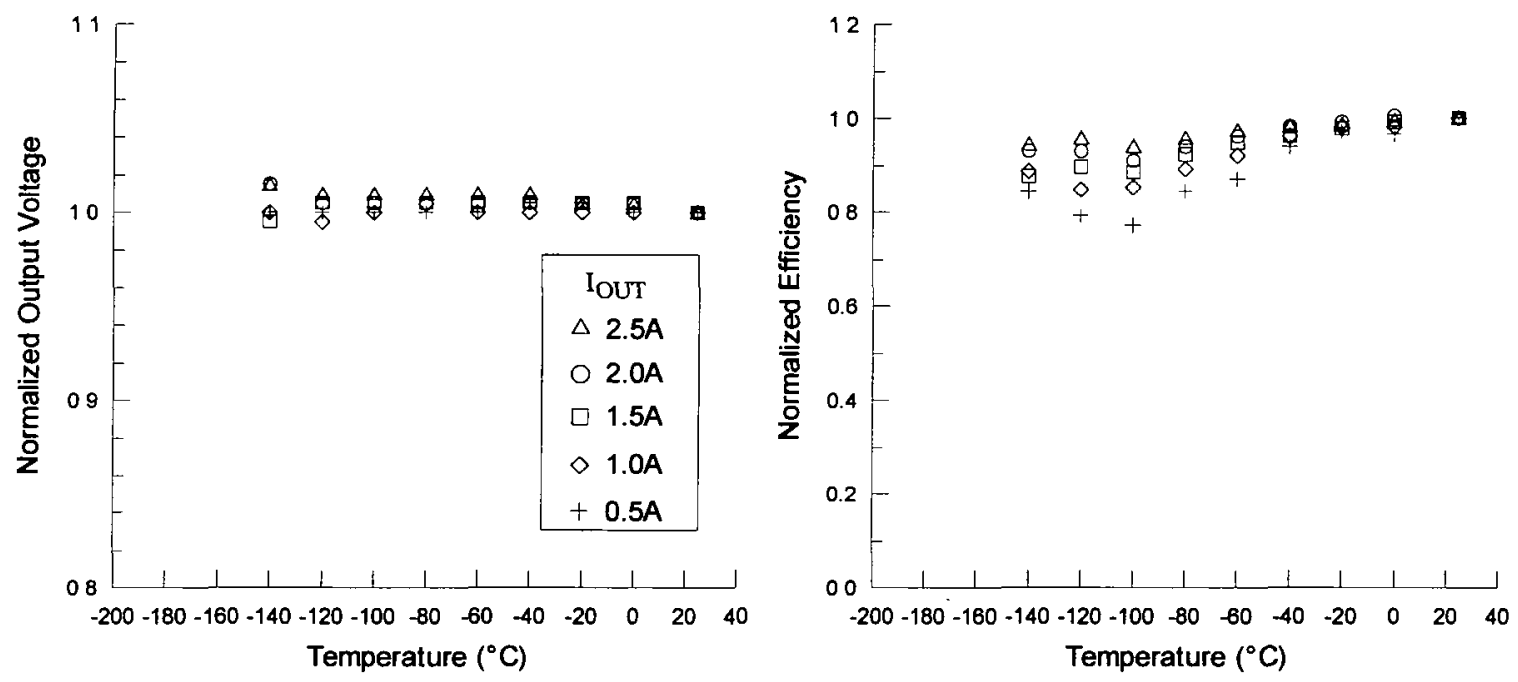

Figure 2. Output voltage and efficiency versus temperature at various loads and input voltage of $24 \mathrm{~V}$.
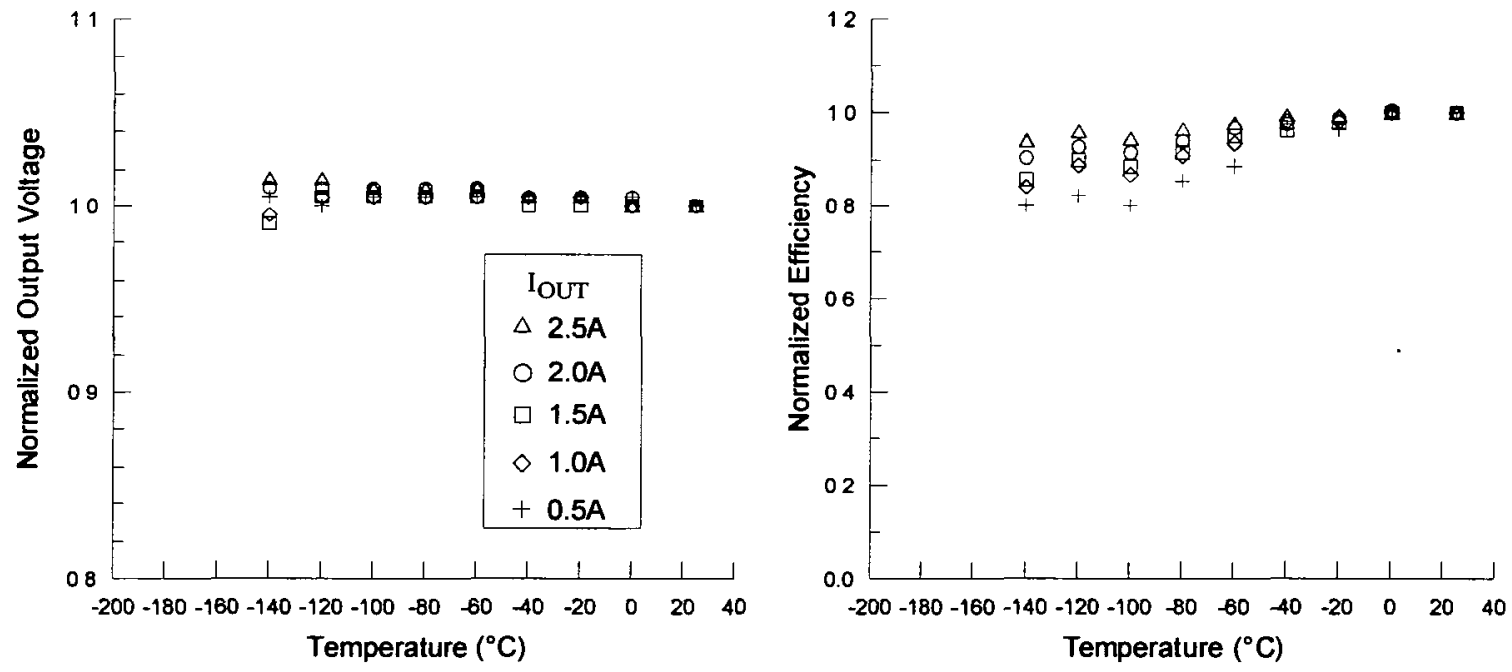

Figure 3. Output voltage and efficiency versus temperature at various loads and input voltage of $32 \mathrm{~V}$.
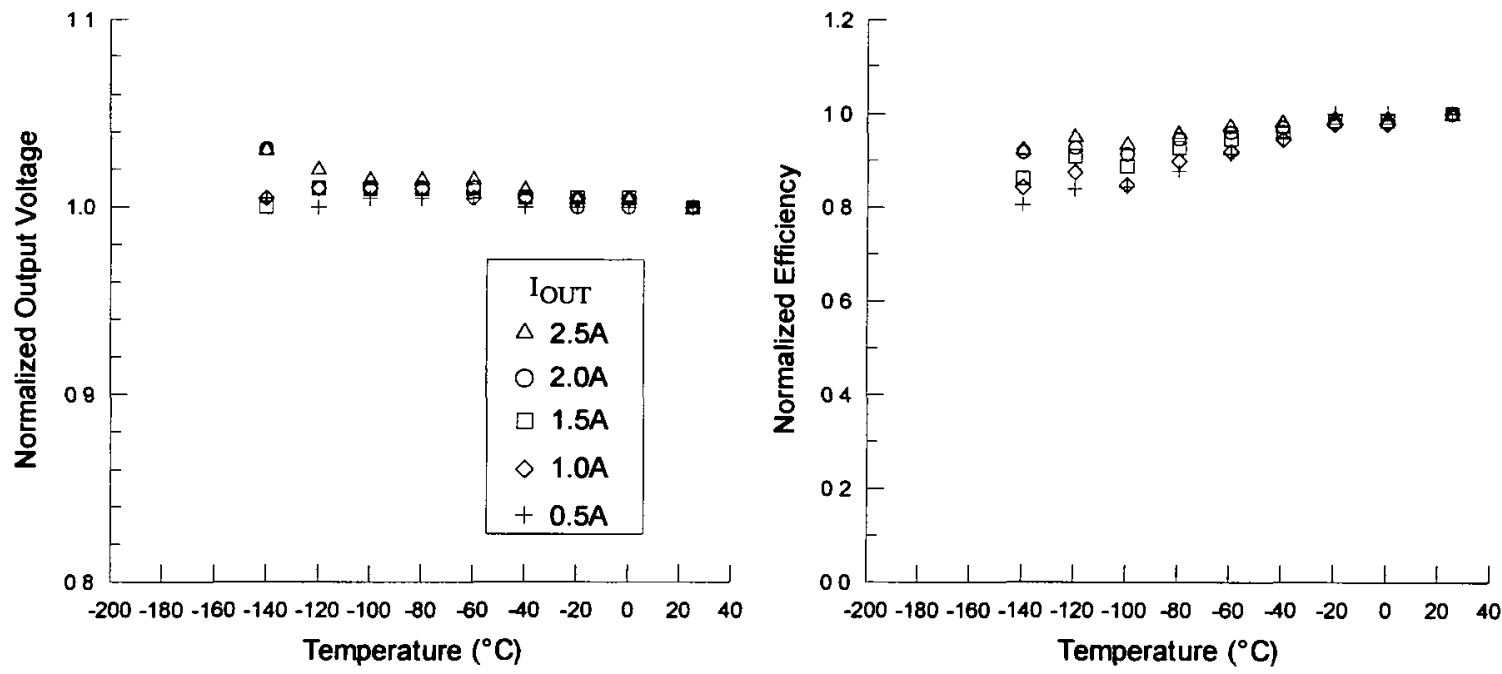

Figure 4. Output voltage and efficiency versus temperature at various loads and input voltage of $40 \mathrm{~V}$. 

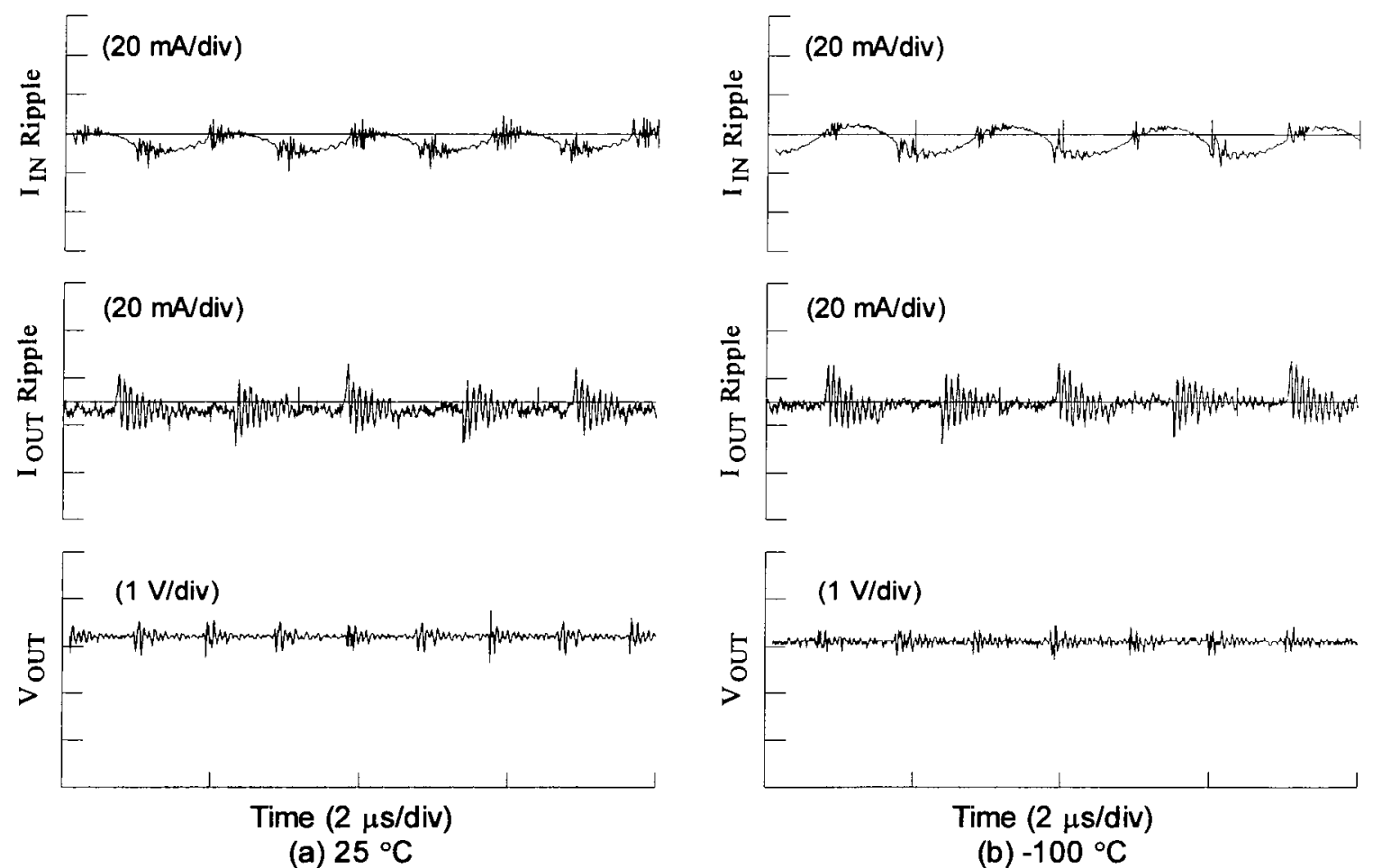

Figure 5. The converter ripple characteristics at low input voltage (16 V) and under light load (1.0 A).
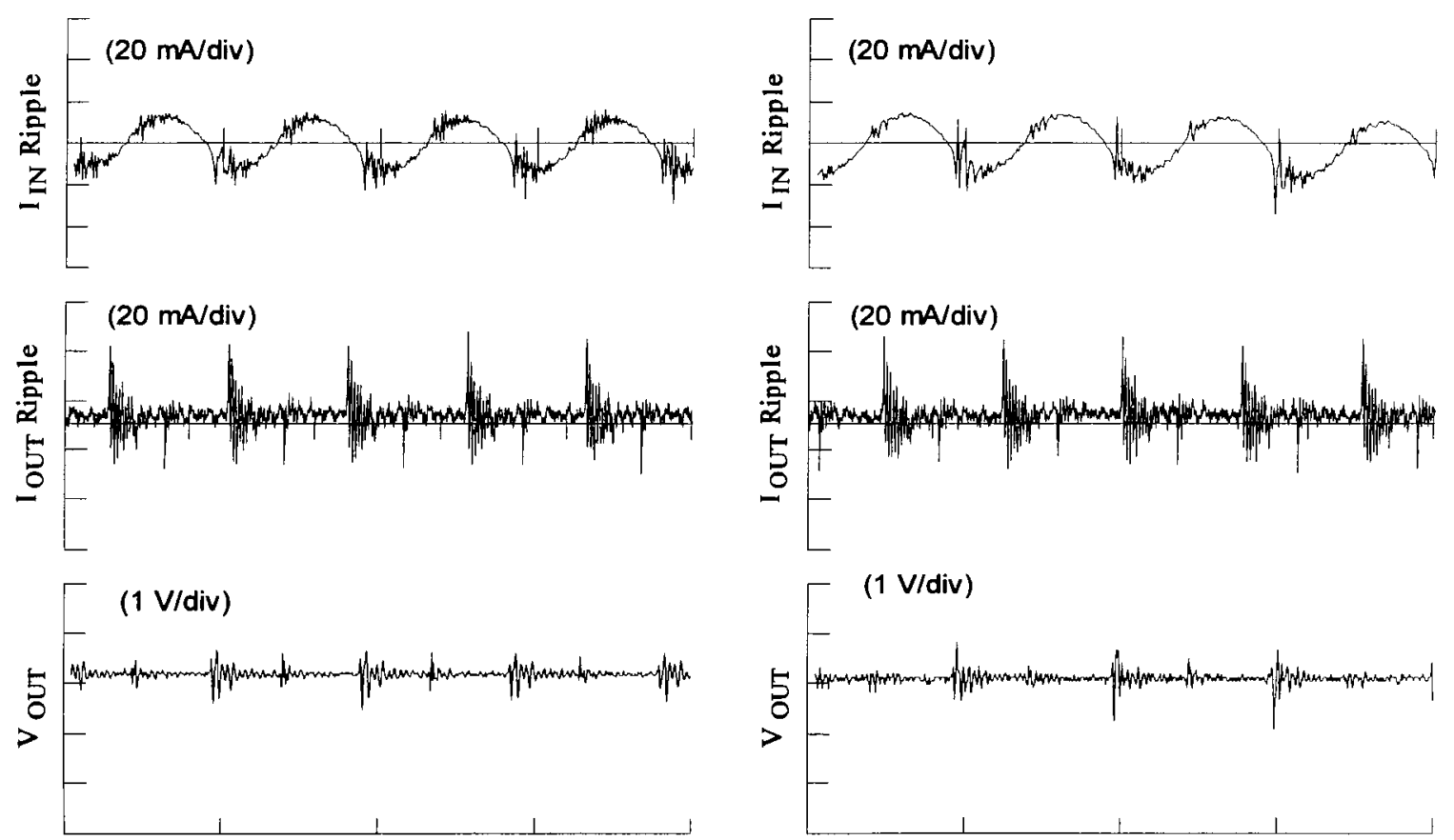

Time $(2 \mu \mathrm{s} / \mathrm{div})$

(a) $25^{\circ} \mathrm{C}$

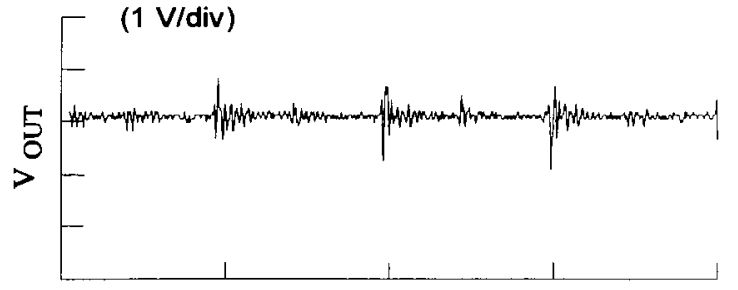

Time $(2 \mu \mathrm{s} / \mathrm{div})$

(b) $-100^{\circ} \mathrm{C}$

Figure 6. The converter ripple characteristics at low input voltage $(16 \mathrm{~V})$ and under heavy load $(2.5 \mathrm{~A})$. 

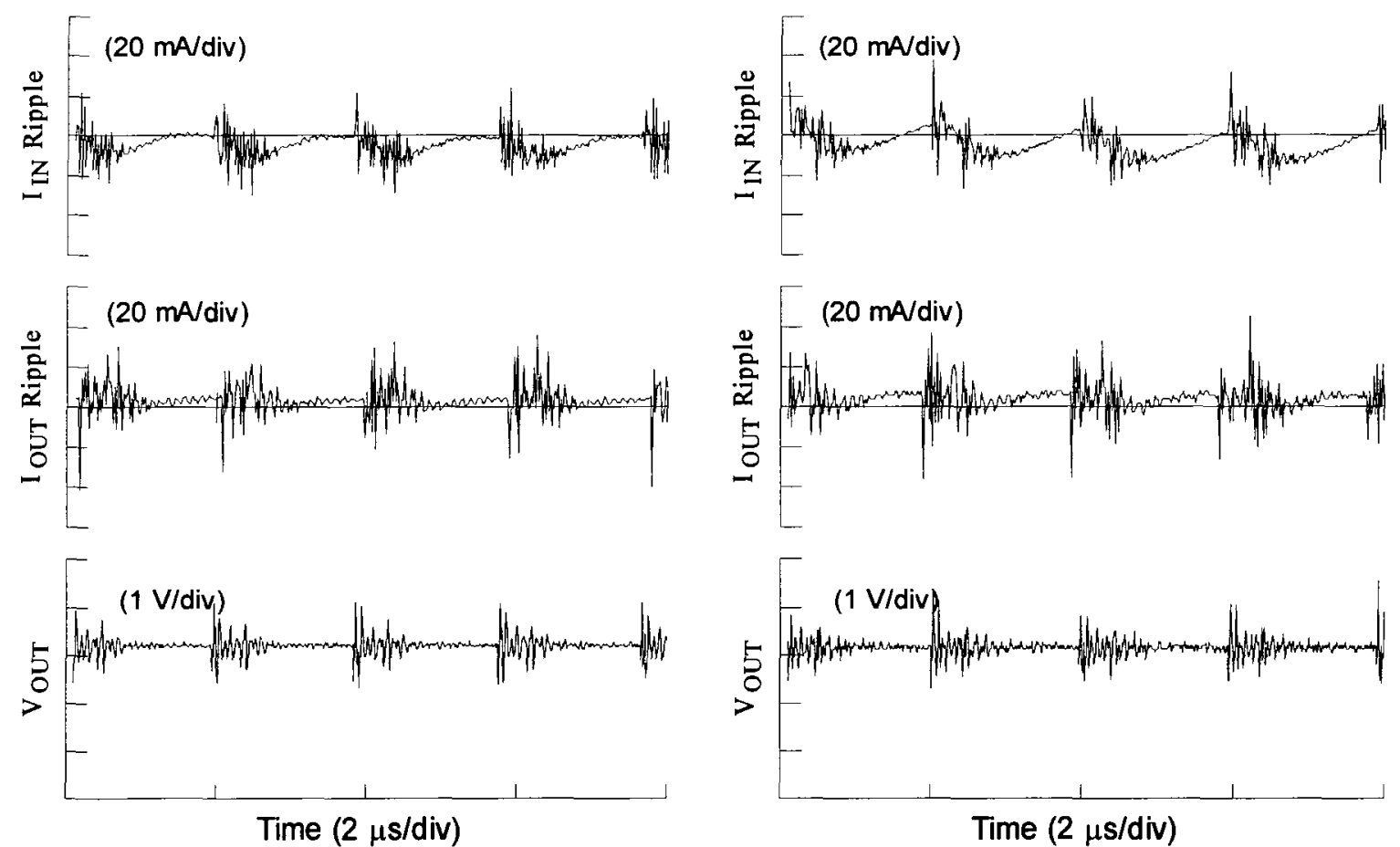

(a) $25^{\circ} \mathrm{C}$

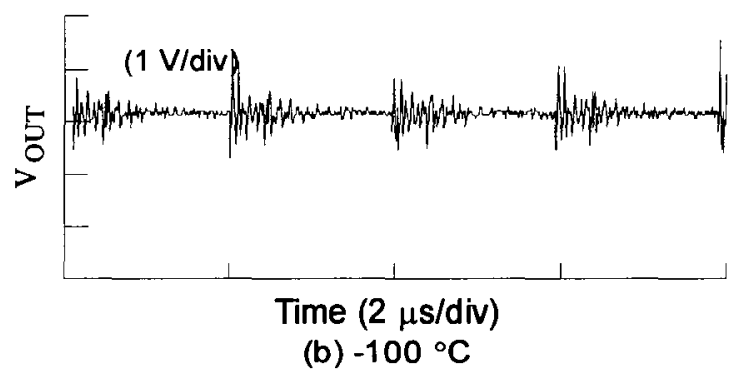

Figure 7. The converter ripple characteristics at high input voltage $(40 \mathrm{~V})$ and under light load $(1.0 \mathrm{~A})$.
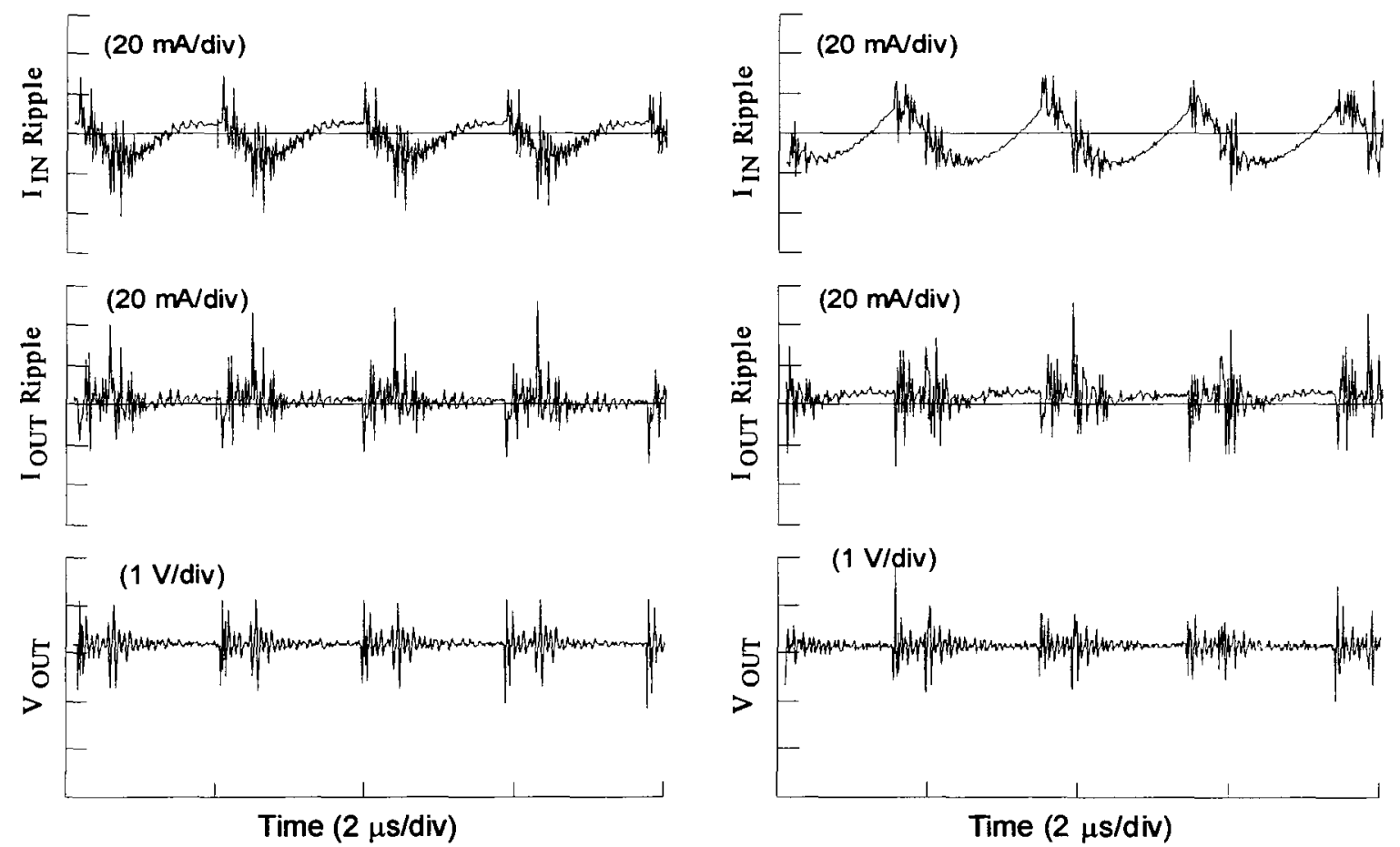

(a) $25^{\circ} \mathrm{C}$

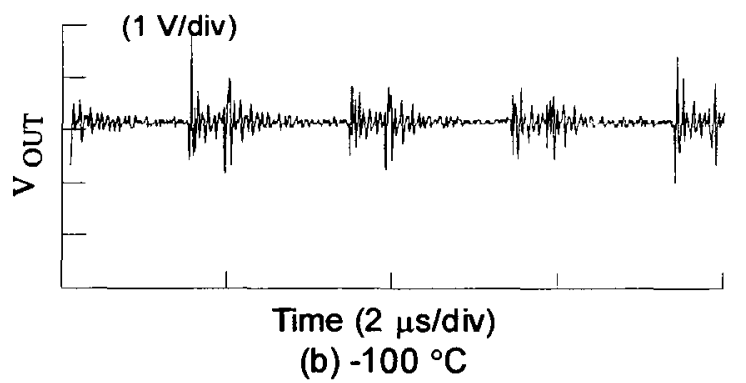

Figure 8. The converter ripple characteristics at high input voltage $(40 \mathrm{~V})$ and under heavy load $(2.5 \mathrm{~A})$. 

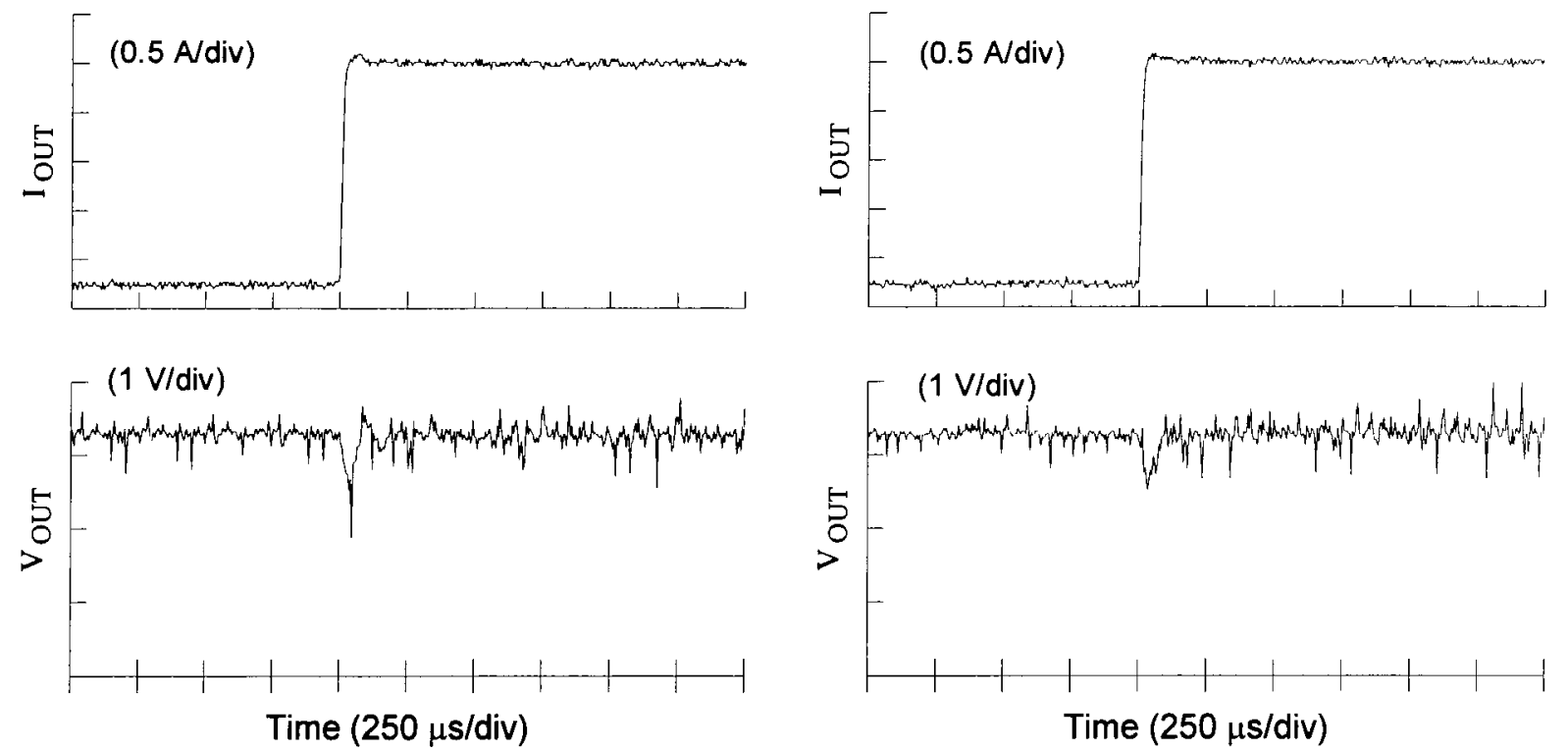

(a) $25^{\circ} \mathrm{C}$

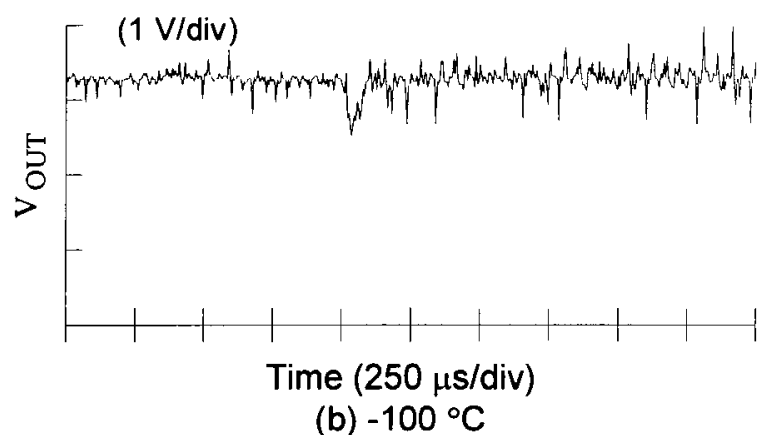

Figure 9. The converter dynamic response to a step change from no-load to full-load at an input voltage of $16 \mathrm{~V}$.
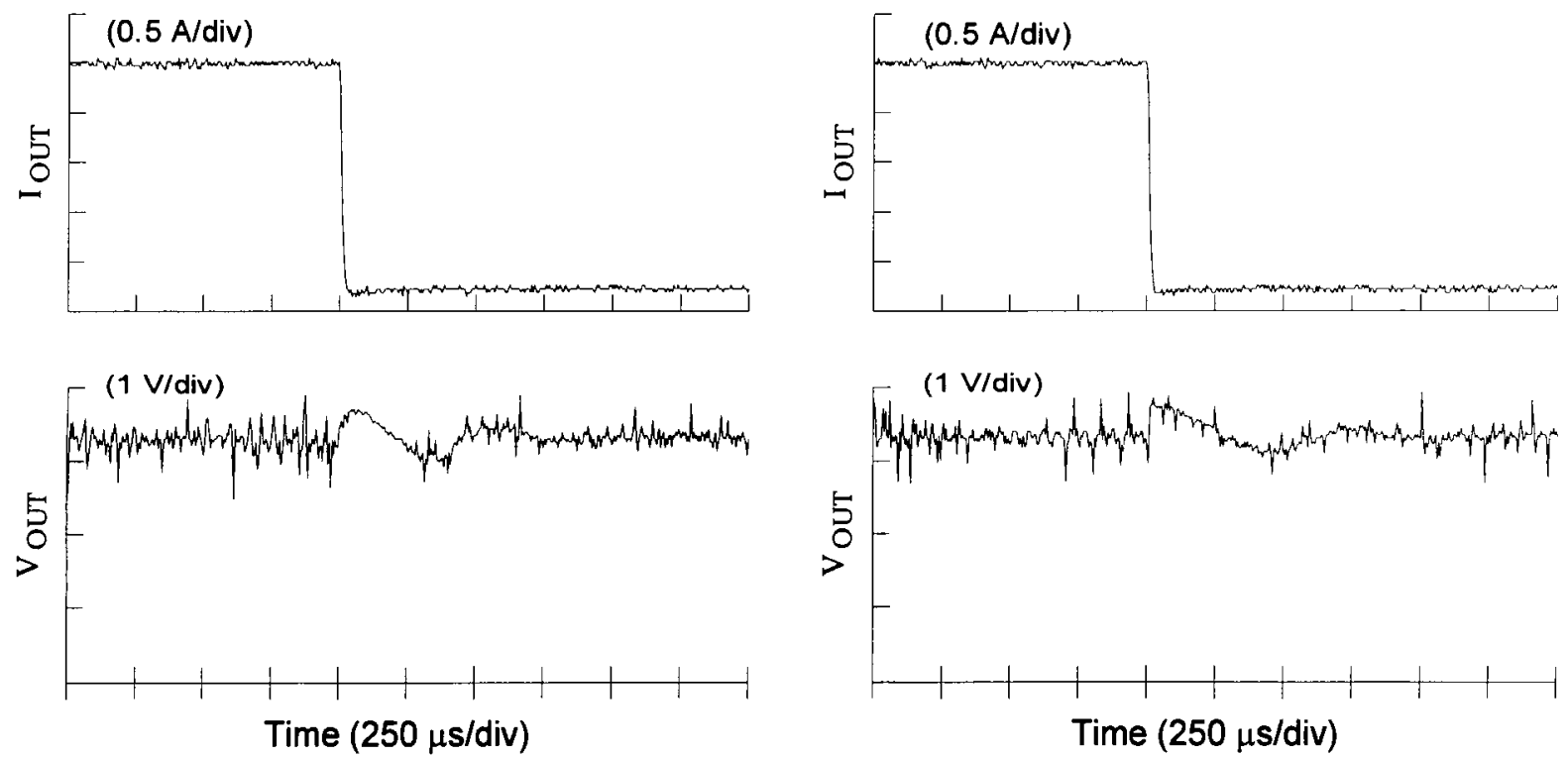

(a) $25^{\circ} \mathrm{C}$

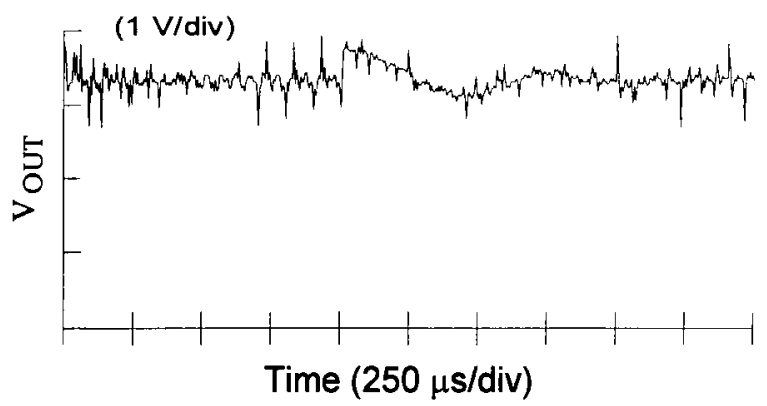

(b) $-100^{\circ} \mathrm{C}$

Figure 10. The converter dynamic response to a step change from full-load to no-load at an input voltage of $16 \mathrm{~V}$. 
Public reporting burden for this collection of information is estimated to average 1 hour per response, including the time for reviewing instructions, searching existing data sources, gathering and maintaining the data needed, and completing and reviewing the collection of information. Send comments regarding this burden estimate or any other aspect of this collection of information, including suggestions for reducing this burden, to Washington Headquarters Services, Directorate for Information Operations and Reports, 1215 Jefferson Davis Highway, Sulte 1204, Arlington, VA 22202-4302, and to the Office of Management and Budget, Paperwork Reduction Project (0704-0188), Washington, DC 20503

\begin{tabular}{|l|c|c|}
\hline 1. AGENCY USE ONLY (Leave blank) & $\begin{array}{c}\text { 2. REPORT DATE } \\
\text { January } 2003\end{array}$ & $\begin{array}{c}\text { 3. REPORT TYPE AND DATES COVERED } \\
\text { Technical Memorandum }\end{array}$ \\
\hline
\end{tabular}

\section{TITLE AND SUBTITLE}

January 2003

Cryogenic Evaluation of an Advanced DC/DC Converter Module for Deep Space Applications

6. AUTHOR(S)

Malik E. Elbuluk, Ahmad Hammoud, Scott S. Gerber, and Richard Patterson

\section{PERFORMING ORGANIZATION NAME(S) AND ADDRESS(ES)}

National Aeronautics and Space Administration

John H. Glenn Research Center at Lewis Field

Cleveland, Ohio 44135-3191

9. SPONSORINGMONITORING AGENCY NAME(S) AND ADDRESS(ES)

National Aeronautics and Space Administration

Washington, DC 20546-0001
5. FUNDING NUMBERS

WBS-22-297-60-05

8. PERFORMING ORGANIZATION REPORT NUMBER

$\mathrm{E}-13738$

10. SPONSORINGMONITORING AGENCY REPORT NUMBER

NASA TM-2003-212085

11. SUPPLEMENTARY NOTES

Prepared for the 37th Industry Application Society Annual Meeting cosponsored by the Institute of Electrical and Electronics Engineers and the Instrument Society of America, Pittsburgh, Pennsylvania, October 13-17, 2002. Malik E. Elbuluk, University of Akron, Akron, Ohio 44325; Ahmad Hammoud, QSS Group, Inc., Cleveland, Ohio 44135; Scott S. Gerber, ZIN Technologies, Inc., Brook Park, Ohio 44142; Richard Patterson, NASA Glenn Research Center. Responsible person, Malik E. Elbuluk, organization code 5480, 216-433-8189.

128. DISTRIBUTION/AVAILABILITY STATEMENT

Unclassified - Unlimited

Subject Category: 33

Distribution: Nonstandard

Available electronically at http://gltrs.grc.nasa.gov

This publication is available from the NASA Center for AeroSpace Information, 301-621-0390.

13. ABSTRACT (Maximum 200 words)

DC/DC converters are widely used in power management, conditioning, and control of space power systems. Deep space applications require electronics that withstand cryogenic temperature and meet a stringent radiation tolerance. In this work, the performance of an advanced, radiation-hardened (rad-hard) commercial DC/DC converter module was investigated at cryogenic temperatures. The converter was investigated in terms of its steady state and dynamic operations. The output voltage regulation, efficiency, terminal current ripple characteristics, and output voltage response to load changes were determined in the temperature range of 20 to $-140^{\circ} \mathrm{C}$. These parameters were obtained at various load levels and at different input voltages. The experimental procedures along with the results obtained on the investigated converter are presented and discussed.

14. SUBJECT TERMS

DC/DC converter; Cryogenics; Power supplies; Deep space

15. NUMBER OF PAGES

13

17. SECURITY CLASSIFICATION OF REPORT

Unclassified
18. SECURITY CLASSIFICATION OF THIS PAGE

Unclassified
19. SECURITY CLASSIFICATION OF ABSTRACT

Unclassified 